\title{
Comparison of LISA vs INSURE Technique Using Nasal Intermittent Positive Pressure Ventilation (NIPPV) Support In Preterm Infants: A Randomized Controlled Trial
}

\author{
Preterm Bebeklerde Nazal Aralıkı Pozitif Basınçlı Ventilasyon (NIPPV) Desteği kullanılarak \\ LISA ile INSURE Tekniğinin Karşılaştırılması: Randomize Kontrollü Bir Çalışma
}

\author{
Nihal Akcay ${ }^{1}$, Ayşe Sevim Gökalp ${ }^{2} \oplus$, Ayla Günlemez ${ }^{2} \oplus$, Demet Oğuz ${ }^{2} \oplus$, Fatih Kılıçbay ${ }^{2} \oplus$, Ayşe Engin Arısoy ${ }^{2}$
}

${ }^{1}$ Department of Pediatrics, Kocaeli University, Kocaeli

${ }^{2}$ Department of Neonatology, Kocaeli University, Kocaeli

Received: 01.04.2020 / Accepted: 30.03.2021 / Published Online: 31.03.2021

Cite as: Akcay N, Gökalp AS, Günlemez A, Oğuz D, Kılıçbay F, Engin Arısoy A. Comparison of LISA vs INSURE technique using nasal intermittent positive pressure ventilation (NIPPV) support In preterm infants: a randomized controlled trial. Med J Bakirkoy 2021;17(1):1-6.

\begin{abstract}
Objective: Surfactant administration is usually performed by endotracheal intubation under mechanical ventilation. Less invasive surfactant administration (LISA) technique has became widespread in recent years, in order to prevent the risk of barotrauma and volutrauma caused by mechanical ventilation and intubation. The aim of this prospective study is to evaluate the effectiveness of surfactant administration via a thin catheter during spontaneous breathing on NIPPV and to compare with INSURE method.

Method: Seventy-eight preterm infants who were born at university hospital with less than 34 weeks of gestational age and who received surfactant therapy were enrolled. The intratracheal administration of poractant alfa (CUROSURF⿻) was performed using umbilical catheters in LISA group ( $n=42)$. INSURE group had 36 infants who were intubated, received surfactant then extubated and placed on NIPPV.

Results: There were no statistically significant differences between two groups in terms of intubation in the first 72 hours and re-administration of surfactant, the duration of NIPPV and the occurence of pneumothorax, pulmonary hemorrhage, patent ductus arteriosus, intraventricular hemorrhage, early onset neonatal sepsis, necrotising enterocolitis, bronchopulmonary dsyplasia and mortality $(p>0.05)$. The $p C \mathrm{O}_{2}$ values decreased faster in LISA group when compared to INSURE group and this difference was statistically significant $(p<0.05)$.

Conclusions: LISA procedure under NIPPV seems to provide better $\mathrm{PCO}_{2}$ levels and does not increased the mortality and morbidity due to technique. Although the results seem to be promising, we need further investigations and larger series.
\end{abstract}

Key Words: INSURE, LISA, Preterm, Surfactant

öz

Amaç: Sürfaktan uygulaması genellikle mekanik ventilasyon altında endotrakeal entübasyon ile yapılır. Mekanik ventilasyon ve entübasyonun neden olduğu barotravma ve volutravma riskini önlemek için son yıllarda daha az invaziv sürfaktan uygulama teknikleri yaygınlaşmıştır. Bu prospektif çalışmanın amacı, NIPPV'de spontan solunum sırasında ince bir kateter yoluyla sürfaktan uygulamasının etkinliğini değerlendirmek ve INSURE yöntemiyle karşılaştırmaktır.

Yöntem: Kocaeli Üniversitesi Hastanesi'nde 34 haftadan küçük doğan ve sürfaktan tedavisine ihtiyaç duyan yetmiş sekiz preterm bebek çalışmaya dahil edildi. LISA grubunda spontan solunum sırasında laringoskopi altında göbek kateterleri kullanılarak sürfaktanın trakeal uygulaması ( $n=42$ ) yapıldı. INSURE grubundaki bebekler entübe edildi, $200 \mathrm{mg} / \mathrm{kg}$ sürfaktan uygulamasındıktan sonra 30 saniye boyunca pozitif basınçı ventilasyon( $n=36)$ uygulandı. Daha sonra ekstübe edildi ve hemen NIPPV'ye alındı.

Bulgular: iki grup arasında ilk 72 saatte entübasyon ihtiyacı ve sürfaktanın tekrar uygulanması, NIPPV süresi, pnömotoraks, pulmoner kanama, patent duktus arteriozus insidansı, intraventriküler kanama, erken sepsis, nekrotizan enterokolit, bronkopulmoner displazi ve mortalite oranları arasında fark yoktu. Parsiyel karbondioksit değerleri LISA grubunda InSurE grubuna göre daha hızlı düştü ve bu istatistiksel olarak anlamliydı.

Sonuçlar: LISA entübasyon gerektirmez, ayrıca uygulanması basit ve kolaydır. Sonuçlar umut verici gibi görünse de, daha fazla araştırmaya ve daha geniş serilere ihtiyacımız var.

Anahtar kelimeler: INSURE, LISA, Pretem, Sürfaktan

Corresponding Author:

drnihalakcay@gmail.com
N. Akcay 0000-0002-8273-2226 A.S. Gökalp 0000-0003-1182-1704
A. Günlemez 0000-0003-1492-3861 D. Oğuz 0000-0003-0727-4875
F. Kılıçbay 0000-0001-9710-0769 A. Engin Arisoy 0000-0003-1880-4114 


\section{INTRODUCTION}

Respiratory Distress Syndrome (RDS) is the most important cause of respiratory problems in preterm infants. The treatment of RDS depends on achieving metabolic, circulatory and respiratory stability, on sustaining adequate oxygenation and ventilation, and on performing surfactant replacement therapy. Although mechanical ventilation (MV) is life-saving, there is a significant liaison between the use of MV and the development of BPD as well as developing neurological sequelae ${ }^{(1)}$. Long-term use of high pressure on immature lungs during $\mathrm{MV}$, is the basic reason for developing BPD, especially in early preterm infants. Therefore, attempts have been discussed to reduce the MV period or to avoid it completely. Noninvasive ventilation -nasal continuous positive airway pressure (NCPAP) or nasal intermittent positive pressure ventilation (NIPPV)-, LISA, INSURE procedures, permissive hypercapnia, early extubation, and caffeine application were the new trends on RDS management ${ }^{(2-3)}$. In the classical surfactant administration surfactant was given through the endotracheal tube and then to ensure its distribution throughout the lungs by applying positive pressure ventilation (4). Another method named INSURE has also been discussed and shown to reduce the need for MV.

In LISA group, the surfactant is administered via a thin catheter into the trachea in spontaneously breathing patients who are recieving NCPAP. This method began to be widely used in Germany in 2001 by Kribs et al. and several positive results were published ${ }^{(5-7)}$. A recent meta-analysis reported that the use of LISA technique reduced the composite outcome of death or bronchopulmonary dysplasia (BPD) at 36 weeks of gestational age ${ }^{(8)}$. The aim of this prospective study is to evaluate the effectiveness of LISA during spontaneous breathing on NIPPV and to compare with INSURE technique.

\section{METHODS}

This was a prospective single-centered randomised controlled study. Ninety-two preterm infants less than 34 weeks of gestational age (GA) who were born at university hospital and who were diagnosed with RDS and required surfactant therapy were assessed. Seventy-eight infants were enrolled in the study. The trial was approved by the local ethics committee (kou kaek2014/99), and written informed parental consent was obtained for each infant.

Infants were randomly assigned to LISA or INSURE by using sequential numbers generated at the IT department of the NICU by 1:1 allocation ratio. Infants were randomized either in LISA group $(n=42)$ or in INSURE group $(n=36)$.

Preterm infants were put on nasal CPAP in the delivery room and were transported to NICU by a transport incubator while being monitored by pulse oximetry. Infants who were suffering from the signs of RDS (tachypnea, grunting, intercostal retractions, typical chest X-ray or blood gas findings) on NCPAP and who required fraction of inspired oxygen $\left(\mathrm{FiO}_{2}\right)$ above $40 \%$ at 26-34 weeks of $\mathrm{GA}$ and $\mathrm{FiO}_{2}$ above $30 \%$ under 26 weeks of GA in the first 2 hours of life to maintain $\mathrm{SpO}_{2}$ levels between $90 \%$ to $94 \%$, were randomized to receive early surfactant treatment either by LISA or INSURE procedure.

Infants with major congenital anomalies or hydrops fetalis, who needed intubation in the delivery room and who had no parental consent, were excluded from the study. The poractant alfa (CUROSURF ${ }^{\circledR}$ ) $(200 \mathrm{mg} / \mathrm{kg})$ was endotracheally administered using 3.5 F (Plastimed) umbilical catheters under direct laryngoscopy in spontaneously breathing infants who were on NIPPV. At least two healthcare providers performed the procedure. The infants were monitored throughout the entire procedure. Initial ventilatory settings were as follows; rate: 60, IT: 0.35 second, PEEP $6 \mathrm{~cm} \mathrm{H}_{2} \mathrm{O}$, PIP $15-20 \mathrm{~cm} \mathrm{H}_{2} \mathrm{O}$, and target $\mathrm{SPO}_{2}$ was $90-95 \%$. The adjustments were made regarding the patients' needs. NIPPV was applied with the help of nasal prongs (Fisher Paykel).

In the INSURE procedure, the infants were intubated, and they received positive pressure ventilation by mechanical ventilator (Drager Evita XL Ventilator) for 30 seconds after $200 \mathrm{mg} / \mathrm{kg}$ of poractant administration, and then they were extubated and placed on NIPPV immediately. Sedation or analgesia were not applied as premedication in either groups.

The second and the third surfactant treatments were 
TABLE 1: Maternal and neonatal demographic characteristics of the groups.

\begin{tabular}{|l|l|l|l|}
\hline Demographic Features & $\begin{array}{l}\text { LISA } \\
\mathrm{n}: 42\end{array}$ & $\begin{array}{l}\text { INSURE } \\
\mathrm{n}: 36\end{array}$ & $\mathrm{p}$-value \\
\hline Gestational age (weeks) Median (25-75 Percentiles) & $29.0(27.0-32.0)$ & $30.5(28.0-32.0)$ & 0.303 \\
\hline Birth weight (grams) Median (25-75 Percentiles) & $1250(1010-1605)$ & $1200(955-1767.5)$ & 0.992 \\
\hline 1 Min Apgar score Median (25-75 Percentiles) & $6.0(6.0-7.0)$ & $7.0(6.0-8.0)$ & 0.012 \\
\hline 5 Min Apgar score Median (25-75 Percentiles) & $8.0(7.0-9.0)$ & $9.0(7.3-9.0)$ & $\mathbf{0 . 0 2 5}$ \\
\hline Male gender, $\mathrm{n}(\%)$ & $21(50)$ & $14(38.9)$ & 0.450 \\
\hline C-section, $\mathrm{n}(\%)$ & $41(97.6)$ & $35(97.2)$ & 1.000 \\
\hline Delivery room stabilization: Oxygene $\mathrm{n}(\%), \mathrm{nCPAP} \mathrm{n}(\%)$ & $22(52.4)$ & $17(47.2)$ & 0.523 \\
\hline Antenatal steroids, $\mathrm{n}(\%)$ & $20(47.6)$ & $19(52.8)$ & \\
\hline Chorioamnionitis, $\mathrm{n}(\%)$ & $27(64.3)$ & $26(72.2)$ & 0.737 \\
\hline PPROM, $\mathrm{n}(\%)$ & $1(2.4)$ & $2(5.6)$ & 0.593 \\
\hline GDM, $\mathrm{n}(\%)$ & $8(19)$ & $4(11.1)$ & 0.513 \\
\hline GHT, $\mathrm{n}(\%)$ & $5(11.9)$ & $1(2.8)$ & 0.132 \\
\hline Preeclampsia, $\mathrm{n}(\%)$ & $2(4.8)$ & $1(2.8)$ & 0.650 \\
\hline Eclampsia, $\mathrm{n}(\%)$ & $13(30.9)$ & $13(36.1)$ & 0.630 \\
\hline
\end{tabular}

PPROM: Premature prolonged ruptures of membranes, GDM: Gestational diabetes mellitus, GHT: Gestational hypertension, $\mathrm{n}$ (\%), Median (25-75 Percentiles), Mann-Whitney U Test, Yates Chi Square test, Student t test

based on the European consensus criteria ${ }^{(9)}$. The patients who required repeating doses of surfactant but did not require intubation, received $100 \mathrm{mg} / \mathrm{kg}$ of surfacfant with the same method in the allocation arm. The repeating doses were given via endotracheally if the infant was intubated.

Frequent episodes of apnea, respiratory acidosis in blood gas analysis and $\mathrm{FiO}_{2}>50 \%$ were used as criteria for intubation following the first surfactant administration.

The demographical data and outcome of the infants were comprised of the body weight, sex, APGAR scores, the delivery room respiratory support, the need for intubation in the first 72 hours, the days on NIPPV and blood gas analyses, the existence of PDA, NEC and clinical sepsis, the days of oxygen dependency, ROP, BPD, IVH, the length of hospital stay, and death before discharge. Intraventricular haemorrhage was staged as described by Volpet et al ${ }^{(10)}$. Only the subjects who met the NIH consensus definition were included in BPD group ${ }^{(1)}$.

\section{Statistical Analyses}

All statistical analyses were performed using IBM SPSS for Windows version 20.0 (SPSS, Chicago, IL, USA). Kolmogorov-Smirnov test was used to test the normality of the data distribution. The continuous variables were expressed as the mean \pm standard deviation and the median (25. percentiles-75. percentiles). The categorical variables were expressed as counts (percentages). The comparisons of the continuous variables between the groups were performed using Student's t- test, Mann Whitney U-Test, Two-sample Kolmogorov-Smirnov Test, Paired samples t- test and Wilcoxon t- test. The comparisons of the categorical variables between the groups were performed using Monte Carlo Chi Square Test. A two-sided $\mathrm{P}$ value $<.05$ was considered statistically significant.

\section{RESULTS}

A total of 78 infants were randomised to one of the two groups of LISA and INSURE (Fig. 1).There were no significant differences in patient characteristics between the two study groups (LISA vs INSURE: median birth body weight was $1250 \mathrm{~g}$ vs $1200 \mathrm{~g}$, respectively; median gestational age at birth was 29 weeks vs 30.5 weeks, respectively). Only, APGAR scores were shown statistically significant difference between two groups lower in LISA group (Table 1).

There was no statistically significant difference between the two groups in terms of the need for intubation in 


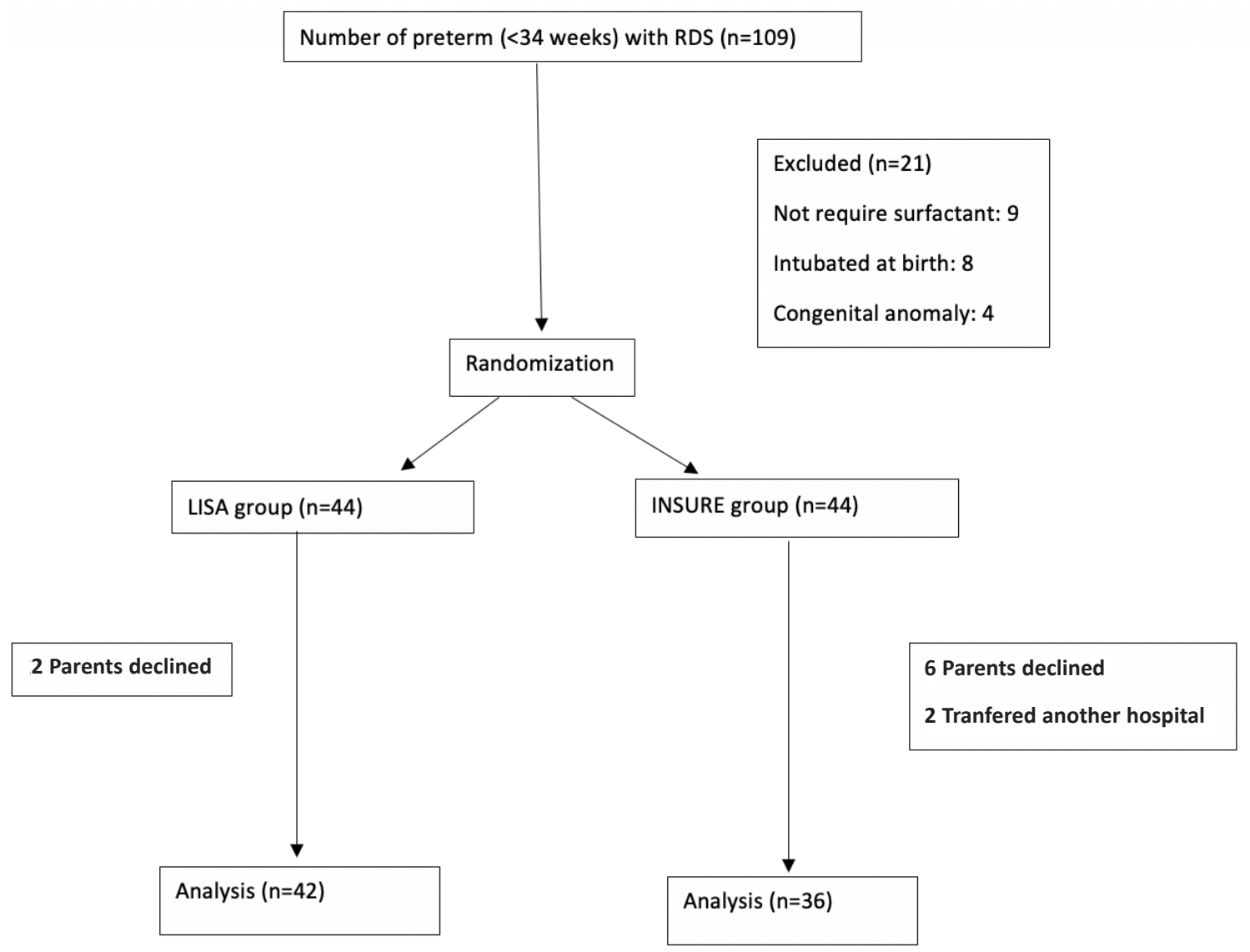

the first 72 hours and for repetitive doses of surfactant. In LISA group, 7 (16\%) infants received second doses of surfactant, however no infant received third dose. In INSURE group, 8 (22\%) infants received second dose of surfactant and 4 (11\%) infants received third dose. $\mathrm{PCO}_{2}$ values dropped rapidly in LISA group compared to INSURE group and this difference was statistically significant $(p<0.001)$ (Table 2).

The need for intubation within the first 72 hours and re-administration of surfactant, the duration of NIPPV, the occurrence of complications such as pneumothorax, pulmonary hemorrhage, PDA, IVH and early sepsis were similar in both groups, and there were no statistically significant differences between the two groups (Table 2). NEC, BPD and mortality rates were found similar in both groups (Table 2).

\section{DISCUSSION}

Surfactant administration via a thin catheter under direct laryngoscopy has gained popularity in recent times. LISA method was first tested in Germany between 2001 and 2002 by Kribs et al (5). The results were published as a feasibility study in 2007. This study showed that the surfactant can be administered with a thin catheter in preterm infants on spontaneous breathing ${ }^{(5-7)}$. In another prospective multicentered study performed in Germany by Kribs et al. (7). 1541 infants under 36 weeks of gestational age and who weigh less than 1500 grams, were evaluated. While 319 infants underwent LISA method, 1222 infants underwent the classical surfactant therapy. In this study, the infants were treated with atropine $5 \mu \mathrm{g} / \mathrm{kg}$ while on NCPAP and neither sedation nor analgesia was implemented. Then a thin catheter was inserted into the trachea under direct laryngoscopy. The laryngoscope was removed after the catheter was placed and then $100 \mathrm{mg} / \mathrm{kg}$ of surfactant was given for 1-5 minutes, and the catheter was then removed. In our study, no sedation or analgesia was applied for premedication and NIPPV was preferred to NCPAP. The reason for using NIPPV is to prevent the surfactant escape from the vocal cords. The surfactant was given to all of the babies at once and it was 
TABLE 2: Neonatal morbidities and mortality rates

\begin{tabular}{|l|l|l|l|}
\hline Outcome parameters & LISA $(\mathrm{n} 42)$ & INSURE $(\mathrm{n} 36)$ & P value \\
\hline Intub first $72 \mathrm{~h}, \mathrm{n}(\%)$ & $15(35.7)$ & $14(38.9)$ & 0.957 \\
\hline Second dose surfactant, $\mathrm{n}, \%$ & $7(6.9)$ & $8(8.1)$ & 1.000 \\
\hline $\mathrm{pH}$ first Median (25-75 Percentiles) & $7.3(7.2-7.3)$ & $7.3(7.3-7.3)$ & 0.360 \\
\hline $\mathrm{pH}$ last Median (25-75 Percentiles) & $7.3(7.3-7.4)$ & $7.3(7.3-7.4)$ & 0.180 \\
\hline $\mathrm{pCO}_{2}$ first Median (25-75 Percentiles) & $56(51-61)$ & $57(52.5-60)$ & 0.507 \\
\hline $\mathrm{pCO}_{2}$ last Median (25-75 Percentiles) & $46.5(42-51)$ & $51(48-55.8)$ & 0.001 \\
\hline Pneumothorax, $\mathrm{n}(\%)$ & $2(4.8)$ & $2(5.6)$ & 1.000 \\
\hline NIPPV (day) Median (25-75 Percentiles) & $3(2-6.25)$ & $3(2-5)$ & 0.395 \\
\hline Oxygene (day) Median (25-75 Percentiles) & $15.5(4-27)$ & $9(5-23)$ & 0.371 \\
\hline EONS, $\mathrm{n}$ (\%) & $6(14.3)$ & $9(25)$ & 0.363 \\
\hline IVH $>$ Grade2, $\mathrm{n}$ (\%) & $1(2.3)$ & $1(2.7)$ & 0.849 \\
\hline PDA required treatment, $\mathrm{n}(\%)$ & & $3(8.3)$ & 1.000 \\
\hline Severe BPD, $\mathrm{n}$ (\%) & $4(9.5)$ & $2(7.1)$ & 0.180 \\
\hline Death, $\mathrm{n}$ (\%) & $3(9.4)$ & $2(7.7)$ & 0.681 \\
\hline
\end{tabular}

Bronchopulmonary dysplasia ( BPD ), Early onset neonatal sepsis (EONS), intraventricular hemorrhage (IVH), patent ductus arteriosus (PDA), n (\%), Median (25-75 Percentiles), Mann-Whitney U Test, Yates Chi Square test, Fisher Chi-Square Test

seen that a minimal leakage occured with this method. We observed that the main factor to prevent this leakage is to use NIPPV instead of NCPAP.

The results of the third study of Kribs et al. reported that the need for the repeating doses of surfactant and the use of doxapram, caffeine, and theophylline were found to be higher in LISA group. Whereas the need for mechanical ventilation in the first 72 hours, the total mechanical ventilation time and oxygen consumption during hospitalisation, the incidence of BPD, death, PDA and severe IVH were found to be significantly lower in LISA group ${ }^{(5-7)}$. In our study, the need for intubation in the first 72 hours was lower in LISA group compared to INSURE group but there was no statistically significant difference between the two groups. Although the percentage of patients who needed repeating doses of surfactant was similar, no infant received a third dose of surfactant in LISA group; however, 4 infants received third dose of surfactant in INSURE group.

The total mechanical ventilation time and the need of oxygen during hospitalisation were higher in LISA group because one of the infants in LISA group was hospitalised for a very long time due to the presence of 3 culture positive sepsis attacks. However, there was no statistically significant difference between the two groups. IVH and PDA were higher in INSURE group; however, there was no statistically significant difference between the two groups. BPD and death were minimally higher in LISA group; however, there was no statistically significant difference between the two groups. The data is difficult to explain, therefore, a larger population will make these results significant. Bradycardia and apnea were not observed during the procedure in LISA group because NIPPV continued throughout the entire procedure and the surfactant was administered rapidly as a bolus.

In a study of Dargavil et al (11), the pneumothorax, BPD, IVH, ROP, NEC prevalance and the duration of mechanical ventilation were similar to those in our study; however, oxygen requirement was significantly lower in LISA group.

In a study of Kanmaz et al (12), the need for the second dose of surfactant and the risk of pneumothorax and pulmonary hemorrhage and the need of intubation in the first 72 hours were found significantly lower in LISA group. In our trial, although LISA was applied to infants with low Apgar scores, we showed significant reduction in $\mathrm{pCO}_{2}$ values in LISA group.

In a study of Aguar et al ${ }^{(13)}$, it was suggested that LISA could be used in the treatment of RDS in preterm infants without the need of sedation and that it had similar results with INSURE. 
In a study conducted by Bao $Y$ et al ${ }^{(14)}$, the need for repeating doses of surfactant, the risk of pneumothorax, BPD, PDA, IVH, ROP, PVL and the length of hospital stay and mortality were found to be similar in both groups. Only the total duration of mechanical ventilation was found to be significantly lower in LISA group.

Finally, in the study of Jena et al (15), it was shown that, the need for MV in the first 72 hours of life was significantly lower, duration of oxygen therapy and hospital stay were significantly shorter with LISA. It reduces the need for mechanical ventilation and hospital stay, and is therefore, in increasing use in NICUs around the world.

Consequently, LISA and INSURE methods can be applied as surfactant replacement therapies. We found that carbon dioxide retention regressed more rapidly after the surfactant therapy using LISA method. We observed that INSURE and LISA methods were not superior to each other because there was no significant difference between the two methods in terms of the clinical data and laboratory findings. Moreover, we think that the use of NIPPV during LISA method decreases the possibility of reflux of the surfactant given and that it positively affects the outcome of LISA method.

In conclusion, LISA does not require intubation, moreover it is simple and easy to be applied. Although the results seem to be promising, we need further investigations and larger series to find out the proper treatment approach.

Ethics Committee Approval: Non-Invasive Research Ethics Committee approval was obtained from Kocaeli University (13.03.2014/2014/99).

Conflict of Interest: No conflict of interest was declared by the authors.

Funding: No funding was used for this study.

Informed Consent: Informed consent was taken from all the participants.

\section{REFERENCES}

1. Jobe AH, Bancalari E. Bronchopulmonary dysplasia. Am J Respir Crit Care Med. 2001;163(7):1723-9. https://doi.org/10.1164/ajrccm.163.7.2011060

2. Rojas MA, Lozano JM, Rojas MX et al. Very early surfactant without mandatory ventilation in premature infants treated with early continuous positive airway pressure: a randomized, controlled trial. Pediatrics.2009;123 (1):137-42. https://doi.org/10.1542/peds.2007-3501

3. Dani C, Bertini G, Pezzati M, Cecchi A, Caviglioli C, Rubaltelli FF. Early extubation and nasal continuous positive airway pressure after surfactant treatment for respiratory distress syndrome among preterm infants $<30$ weeks' gestation. Pediatrics. 2004;113(6):560-3.

https://doi.org/10.1542/peds.113.6.e560

4. Gupta S and Donn SM. Novel approaches to surfactant administration. Hindawi Publishing Corparation Critical Care Research and Practice Volume 2012; 278483:1-5 https://doi.org/10.1155/2012/278483

5. Kribs A, Pillekamp F, Hünseler C, Vierzig A, Roth B. Early administration of surfactant in spontaneous breathing with nCPAP: feasibility and outcome in extremely premature infants (postmenstrual age </=27 weeks). Paediatr Anaesth. 2007;17:364-9. https://doi.org/10.1111/j.1460-9592.2006.02126.x

6. Kribs A, Vierzig A, Hünseler C et al. Early surfactant in spontaneously breathing with nCPAP in ELBW infants-a single centre four year experience. Acta Paediatr.2008;97:293-8. https://doi.org/10.1111/j.1651-2227.2007.00617.x

7. Kribs A, Härtel C, Kattner E, et al. Surfactant without intubation in preterm infants with respiratory distress: first multi-center data. Klin Padiatr 2010;222:13-7. https://doi.org/10.1055/s-0029-1241867

8. Aldana-Aguirre JC, Pinto M, Featherstone RM, Kumar M. Less invasive surfactant administration versus intubation for surfactant delivery in preterm infants with respiratory distress syndrome: a systematic review and meta-analysis. Archives of Disease in Childhood - Fetal and Neonatal Edition 2017;102:F17F23. https://doi.org/10.1136/archdischild-2015-310299

9. Sweet D, Carnielli V, Greisen $\mathrm{G}$ et al. European consensus guidelines on the management of neonatal respiratory distress syndrome in preterm infants-2013 update. Neonatology. 2013;103:353-68

https://doi.org/10.1159/000349928

10. Volpe JJ. Intraventricular hemorrhage in the premature infant-current concepts. Part I. Ann Neurol. 1989;25:3-11 https://doi.org/10.1002/ana.410250103

11. Dargaville PA, Aiyappan A, De Paoli AG et al. Minimally-invasive surfactant therapy in preterm infants on continuous positive airway pressure. Arch Dis Child Fetal Neonat Ed. 2013;98:122-6 https://doi.org/10.1136/archdischild-2011-301314

12. Kanmaz HG, Erdeve O, Canpolat FE, Mutlu B, Dilmen U. Surfactant administration via thin catheter during spontaneous breathing: randomized controlled trial. Pediatrics. 2013;131(2):502-9. https://doi.org/10.1542/peds.2012-0603

13. Aguar M, Cernada M, Brugeda M, Gimeno A, Gutierrez A, Vento $M$. Minimally-invasive surfactant therapy with a gastric tube is as effective as the intubation, surfactant, and extubation technique in preterm babies. Acta Paediatr. 2014;103(6):229-33. https://doi.org/10.1111/apa.12611

14. Bao Y, Zhang G, Wu M, Ma L, Zhu J. A pilot study of less invasive surfactant administration in very preterm infants in a Chinese tertiary center. BMC Pediatrics. 2015;15:1-6 https://doi.org/10.1186/s12887-015-0342-7

15. Jena SR, Bains HS, Pandita A, et al. Surfactant therapy in premature babies: SurE or InSurE. Pediatr Pulmonol. 2019; 54(11):17471752.

https://doi.org/10.1002/ppul.24479 